\title{
Heavily contaminated atmosphere
}

In the era of industrialization, one of the most worrying issues is pollution, notably air pollution which occurs not only in Vietnam but also all around the world. According to the World Health Organization (WHO), air pollution results in deaths of nearly 7 million ${ }^{90}$ people per year. The proportions of more than $95 \%$ 에 of the world's population facing air pollution and over $60 \%$ [i] of people living in bad conditions which do not meet WHO's basic standards were reported by the Health Effects Institute (HEI). Certain data have shown that Vietnam is ranked in the top 10 most polluted ${ }^{4}$ countries in Asia.

When it comes to the origin where this case stemmed from, two major contributing factors need to be listed, namely artificial and natural causes. In particular, while volcanoes, wildfires, dust storms, flora and fauna decomposition lead to natural causes, "Artificial causes are mainly due to the burning fuel of industries which adds sulfur dioxide to the air, traffic overload and human activities" "s. It is because of all the factors mentioned previously that seriously pose threat to the atmosphere, do harm to not only human's well-being but also the environment we are living in, specifically dust, ozone layer depletion, acid rain, etc. Therefore, in order to protect the air as well as not to slow down industrialization and modernization, cutting-edge technology needs to be applied, toxic gas and fuels need to be limited. In addition, it is necessary to develop, invest in methods to purify the air and plant more trees.

In recent years, humans have made certain efforts to improve and prevent the growingly-prevalent- air-pollution. However, we still struggle with diverse difficulties and challenges, typically the remaining problems in the COP26-climate conference. First to be talked about is the "Paris Agreement", which concerns the parties by mentioning the establishing a carbon emission market and allowing nations to exchange carbon credits. Along with language and substance barriers between nations as the Article 6 contains too much technical information, countries' taking advantage of gaps make estimating the amount of greenhouse gas being cut or marketed impossible. Secondly is the problem of "No liability fund". This frustrates developing countries since they need funds to compensate for damages caused by the climate catastrophe. The Glasgow Climate Compact does not call for funding but negotiating although they are aware of losses and damages of nations. In conclusion, this fund can take years to be established provided the parties intend to do so. "in

Human rights' violation: Air pollution has been a global dilemma, it is not only an environmental issue but also a human rights issue. According to David R. Boyd, Special Rapporteur on human rights and the environment for the United Nations, the number of 7 million people who die each year due to air pollution is more than the total number of deaths. war deaths, murder, tuberculosis, HIV, AIDS and malaria combined [12]. Moreover, the United Nations' latest statistics on the environment said that: "If you live in a city in a low or middle-income country, the chances of breathing clean air are very low - $97 \%$ of cities in these countries do not meet air quality guidelines" [10]. All the information and statistics above show that air pollution greatly affects the health of people, especially children, whose benefit needs to be prioritized. People who are destroying the environment also means that their basic rights are being violated by themselves. For decades, governments have considered air pollution as an environmental problem, it has recently begun to be considered as a health problem. Air pollution at the present's 
scale clearly violates the rights to life and health, the rights of children and the right to live in a safe, clean, healthy and sustainable environment [6]. According to Principle 1 of the Stockholm Declaration (1972) of the World Health Organization WHO, which aims to establish the foundation for linking human rights, health, and environmental protection, states that: "Man has the fundamental right to freedom, equality and adequate conditions of life, in an environment of a quality that permits a life of dignity and well-being, and he bears a solemn responsibility to protect and improve the environment for present and future generations" [7]. Environmental conditions clearly help to determine the extent to which people enjoy basic rights to life, health, food and housing, livelihoods and traditional culture.

Government measures: Before the situation of serious air pollution, the Government of each country has different solutions:

According to the Clean Air Fund, in the United States, after the enactment of the Clean Air Act in 1970, the emissions of six common pollutants in this country were monitored under the Clean Air Act and averaged reduction. 69 percent while GDP grew by 238 percent [11].

In India, the New Delhi Air Quality Monitoring Board recommends that all educational institutions should be temporarily closed until further notice due to the air pollution becoming severe and difficult to control. [2].

In Vietnam, the Ministry of Natural Resources and Environment proposed to issue a series of urgent measures to overcome the problem of air pollution, such as developing and implementing a local air quality management plan. ... [5] Recently, on November 23, 2021, the Prime Minister issued Decision 1973/QD-TTg 2021 on "National plan on air quality management for the period 2021-2025" [3].

Solution: Firstly, it is necessary to enact a separate Law on air pollution. Second, it is necessary to be strict in regulations and decrees on compliance with the world's unified air indicators, set forth in the economic and life fields.

Conclusion: In the era of digital technology, humans cannot avoid destroying nature. Having been aware of this circumstance, countries around the world have made their own laws and entered into common alliances to prevent environmental destruction and turn it into a repairable problem. By presenting the realities of society, our group has shown everyone the most honest perspective on air pollution and the measures taken by countries on this problem.

\section{Reference materials}

[1] T. D. T. tức (Theo CNN), "Điểm lại những thành công và thất bại của hội nghị khí hậu COP26," 2021. https://baotintuc.vn/the-gioi/diem-lai-nhung-thanh-cong-va-that-bai-cua-hoi-nghi-khi-hau-cop26 -20211115170816281.htm.

[2] M. Tâm, “Ân Độ : New Delhi đóng cửa trường học do ô nhiễm không khí nghiêm trọng," 2021. 
https://www.vietnamplus.vn/an-do-new-delhi-dong-cua-truong-hoc-do-o-nhiem-khong-khi-nghie m-trong/754445.vnp.

[3] “Quyết định 1973/QĐ-TTg 2021 Kế hoạch quốc gia về quản lý chất lượng môi trường không khí giai đoạn 2021-2025."

https://luatvietnam.vn/tai-nguyen/quyet-dinh-1973-qd-ttg-213038-d1.html.

[4] L. T. Ý, “Ô NHIẼM KHÔNG KHÍ: GIẢI PHÁP TOÀN CÂU VÀ Ở VIẸTT NAM TRONG PHÁT TRIỂN BÊN VỮNG," 2020.

http://greenidvietnam.org.vn/o-nhiem-khong-khi-giai-phap-toan-cau-va-o-viet-nam-trong-phat-tr ien-ben-vung.html.

[5] V. Sơn, "Khắc phục nạn ô nhiễm không khí: Bộ Tài nguyên và Môi trường đề xuất ban hành một loạt biện pháp cấp bách," 2020.

https://baophapluat.vn/khac-phuc-nan-o-nhiem-khong-khi-bo-tai-nguyen-va-moi-truong-de-xuat -ban-hanh-mot-loat-bien-phap-cap-bach-post348554.html.

[6] D. R. Boyd, "The Human Right To Breathe Clean Air," 2019. https://www.ncbi.nlm.nih.gov/pmc/articles/PMC6923778/.

[7] D. Shelton, "HUMAN RIGHTS, HEALTH AND ENVIRONMENTAL PROTECTION: LINKAGES IN LAW AND PRACTICE."

https://www.who.int/hhr/information/Human_Rights_Health_and_Environmental_Protection.pd f.

[8] I. Manisalidis, "Environmental and Health Impacts of Air Pollution: A Review," 2020. https://www.frontiersin.org/articles/10.3389/fpubh.2020.00014/full.

[9] J. M. \& J. Turrentine, "Air Pollution: Everything You Need to Know," 2021. https://www.nrdc.org/stories/air-pollution-everything-you-need-know.

[10] U. N. E. Programme, "Clean air as a human right," 2019. https://www.unep.org/news-and-stories/story/clean-air-human-right.

[11] "U.S. Embassy \& Consulate in Vietnam." https://vn.usembassy.gov/wp-content/uploads/sites/40/2017/03/AQI_FAQ_vi.pdf.

[12] S. Larson, "Time to see air pollution as a human right threat: U.N," 2019. https://www.reuters.com/article/us-health-pollution-rights-idUSKCN1QL268. 